\title{
БИОХИМИЧЕСКИЙ СОСТАВ ПРОДУКТОВ, ПОЛУЧЕННЫХ ПУТЕМ МИКРОБИОЛОГИЧЕСКОЙ КОНВЕРСИИ ЛИГНОЦЕЛЛЮЛОЗНЫХ СУБСТРАТОВ МИЦЕЛИАЛЬНЫМИ ГРИБАМИ
}

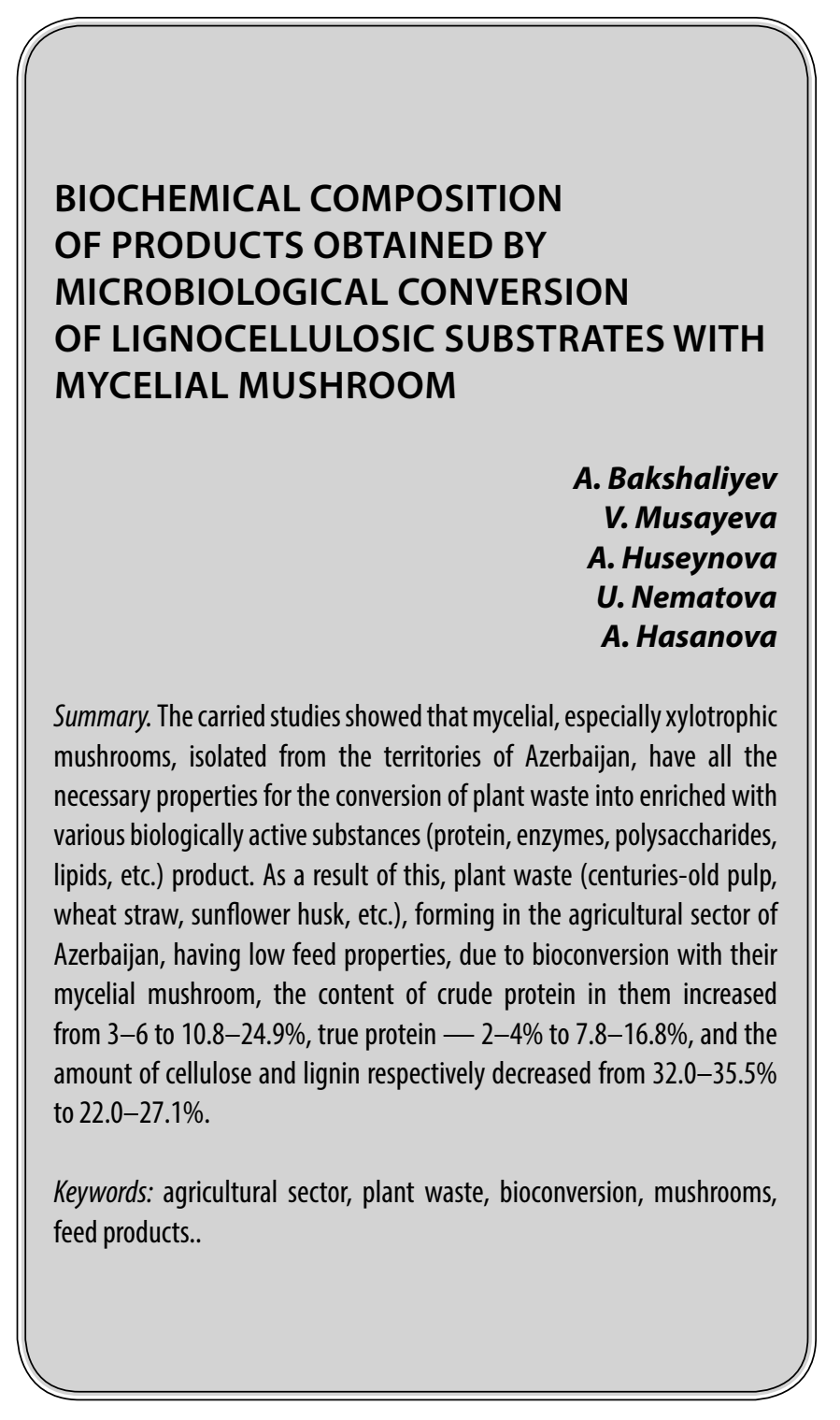

\section{Введение}

$\mathbf{K}$ ак известно, что ежегодно население мира постепенно увеличивается, и это происходит при стабильности территории Земного шара, в результате которого ежегодно уменьшаются возможности Земного шара обеспечить население мира необходимыми продуктами за счет традиционных природных источников [2122]. Именно такое обстоятельство определяет актуальность исследований по получению продуктов микробного
Бахиалиев Арзу Елмар оглы

Сумгаитский Государственный Университет, Азербайджан, г. Сумгаит

baxshaliyev.arzu@mail.ru

Мусаева Вусала Гаджи гызы

Азербайджанский Государственный Экономический Университет, г. Баку efendiyev.nigar@mail.ru

Гусейнова Афсана Энвер гызы

Институт Микробиологии НАН Азербайджана, 2. Баку

efsane_huseynova@mail.ru

Нематова Улкар Вагиф гызы

Азербайджанский Государственный Экономический Университет, г. Баку azmbi@mail.ru

Гасанова Арзу Расул гызы

Сумгаитский Государственный Университет, Азербайджан, г. Сумгаит arzu.h85@mail.ru

Аннотация. В проведенных исследованиях показано, что мицелиальные, особенно ксилотрофные грибы, выделенных из территорий Азербайджана, обладают всеми необходимыми свойствами для конверсии растительные отходы в обогащенным разными биологически активными веществами (белок, ферменты, полисахариды, липиды и др.) продукт. В результате этого, растительные отходы (векловичный жом, пшеничная солома, подсолнечная лузга и др.), образующие в аграрном сектора Азербайджана, имеющие низкие кормовые свойства, за счет биоконверсии их мицелиальными грибами содержание сырого протеина в них увеличивалось с 3-6 до 10,8$24,9 \%$, истинного белка - 2-4\% до 7,8-16,8\%, а количество целлюлоза и лигнина соответственно уменьшалось с $32,0-35,5 \%$ до 22-27,1\%.

Ключевые слова: аграрный сектор, растительные отходы, биоконверсия, грибы, пищевые продукты.

синтеза путем биоконверсии растительных субстратов[11, 16], которые возобновляются в процессе фотосинтеза.

Ежегодно, в результате фотосинтеза, образуется огромное количество зеленой биомассы и ее определенная часть - примерно 10\% используется для удовлетворения потребностью мировой населению в энергии [22]. В ходе использования образуется многотоннажное вещество, которое не пригодно без дополнительной переработки. В связи с образованием предельно боль- 
шого количества растительных отходов[10], приведение их в состояние пригодности с точки зрения практической необходимости, из-за ряда причин, является одной из актуальных задач современной науки, в том числе биологической.

Растительные отходы имеют очень сложную структуру и в их состав входят такие высокомолекулярные полимеры как целлюлоза, лигнин, гемицеллюлоза, пектин и др. [17, 19-20]. Именно это является основным фактором, затрудняющим их использование в образованном виде без дополнительной переработки. Поэтому первой задачей необходимой для использования отходов в практических нуждах является превращение их в вещество, имеющее низкомолекулярный состав.

В настоящее время для решения данной проблемы используют разные подходы, наиболее перспективным из которых является биологический способ утилизации, прежде всего микробиологический и энзимологический $[1,10]$. Так как переработка отходов биологическим способом, в продукт полезный в практических целях, позволила бы не только сберечь первичный материал, расширить в значительной мере сырьевую базу многой промышленности (микробиологической, биотехнологии и др.), но и существенно уменьшить загрязнение окружающей среды[2-5, 15].

Уже на протяжении нескольких лет в данной области проводятся исследования и в полученных результатах в основном показана возможность получения обогащенных белками, витаминами и другими биологически активными веществами продуктов разного (пищевого и кормового) назначения путем микробиологической конверсии растительных отходов[7-8, 11, 18]. Однако применение в практике полученных результатов в широком плане остается не решенным, что связано с рядом недостатков разного характера (экономический, экологический, технологический и др.). Среди них в первую очередь следует отметить нехватку продуцентов, имеющих необходимую биологическую активность для эффективной утилизации растительных отходов путем микробиологической конверсии, что в свою очередь предопределяет актуальность исследований, посвященных устранению названных недостатков.

При микробиологической конверсии таких отходов как правило предпочтение отдается мицелиальным, первый очередь ксилотрофным грибам [1, 11, 15], что легко объяснимо. Так как эти грибы являются активным продуцентом ни только белков, витаминов, но ферментов широкого спектра действия [10]. Кроме того, образуемый ими белок имеет хороший, сбалансированный аминокислотный состав, содержание нуклеиновых кислот в образованных продуктах очень низкий и т.п.
Применение мицелиальных грибов в практике требует тщательного изучения состава и биологической ценности продуктов, получаемых с их помощью, что и явилось целью представленной работы.

\section{материалы и метомы}

Для биоконверсии лигноцеллюлозных субстратов использовали следующие грибы: Aspergillus niger, Bjerkandera adusta, Cerrena unicolar, Ganoderma lucidum, Penicillium verriculosum, Pleurotus ostreatus, Polypous aqariceus, Trametes hirsutus, T.versicolor, и Trichoderma liqnorum, которые выделили в чистую культуры в ходе исследований из разных территорий Азербайджана.

В качестве субстрата были взяты свекловичный жом, пшеничная солома, подсолнечная лузга, опилки широколиственных деревьев и кукурузные кочерыжки, которые образуется в аграрном сектора Азербайджана [11]. Использованные субстраты подвергались только механическим способам предобработки, т.е. измельчали.

Качество продуктов пищевого и кормового назначения определяется наличием традиционных компонентов - белков, жиров, нуклеиновых кислот, целлюлозы, лигнина, гемицеллюлозы и др., количество которых определяли известным методом [6, 9, 12-14].

Процесс проводили в условиях жидкофазной (ЖФФ) и твердофазной (ТФФ) ферментации согласно известным методом.

\section{Полученные результаты} и их обсужАение

В результате ферментации растительных отходов содержание сырого протеина в них увеличивалось с 3-6 до $10,8-24,9 \%$, истинного белка - 2-4\% до 7,8-16,8\%, а количество целлюлоза уменьшалось с 32,0-35,5\% до 22,0-27,1\% (табл. 1). Биологическая ценность белков определяется в первую очередь степенью сбалансированности аминокислот и процентным содержанием незаменимых. В полученных нами биомассах последний показатель колеблется в пределах 36-48\%. Для сравнения можно вспомнить, что количество незаменимых аминокислот в составе пшеничного белка составляет 30-32\%, дрожжевой - 38-49\%, мясо говядины до $45 \%$.

По сравнению с идеальным белком по ФАО, продукты ферментации лимитированы серосодержащими аминокислотами [4], в то же время по другим аминокислотам продукты ферментации превышают требуемый уровень. В целом содержание аминокислот в белках ферментированных субстратов отвечает требованиям к продуктам, 
Таблица 1. Состав (\%) полученных препаратов путем микробиологический конверсии растительных отходов мицелиальными грибами

\begin{tabular}{|c|c|c|c|c|c|c|}
\hline Продуцент & $\begin{array}{l}\text { Сырой } \\
\text { протеин }\end{array}$ & Белок & $\begin{array}{l}\text { Сырой } \\
\text { жир }\end{array}$ & $\begin{array}{l}\text { Целю- } \\
\text { лоза }\end{array}$ & Зола & $\begin{array}{l}\text { Нуклеиновые } \\
\text { кислоты }\end{array}$ \\
\hline \multicolumn{7}{|l|}{ ЖФФ } \\
\hline $\begin{array}{l}\text { T, hirsutus } \\
\text { T.versicolor } \\
\text { B.adusta } \\
\text { P.aqariceus } \\
\text { P.ostreatus } \\
\text { C.unicolar } \\
\text { G.lucidum } \\
\text { A.niger } \\
\text { P. verriculosum } \\
\text { T.liqnorum }\end{array}$ & $\begin{array}{l}20,7 \\
20,1 \\
22,0 \\
21,5 \\
22,4 \\
18,9 \\
17,9 \\
23,7 \\
24,9 \\
20,2\end{array}$ & $\begin{array}{l}13,2 \\
13,2 \\
15,1 \\
14,0 \\
15,1 \\
12,7 \\
11,8 \\
16,0 \\
16,8 \\
13,0\end{array}$ & $\begin{array}{l}2,4 \\
2,1 \\
2,5 \\
2,6 \\
2,2 \\
2,1 \\
2,3 \\
2,8 \\
3,0 \\
2,5\end{array}$ & $\begin{array}{l}25,5 \\
24,5 \\
25,8 \\
26,5 \\
23,6 \\
24,2 \\
24,7 \\
24,7 \\
26,8 \\
24,0\end{array}$ & $\begin{array}{l}3,2 \\
3,1 \\
3,9 \\
3,8 \\
3,0 \\
3,6 \\
3,8 \\
4,5 \\
4,8 \\
5,0\end{array}$ & $\begin{array}{l}0,74 \\
0,70 \\
0,65 \\
0,67 \\
0,57 \\
0,61 \\
0,52 \\
0,46 \\
0,79 \\
0,42\end{array}$ \\
\hline \multicolumn{7}{|l|}{ ТФФ } \\
\hline $\begin{array}{l}\text { T. hirsutus } \\
\text { T.versicolor } \\
\text { B.adusta } \\
\text { P.aqariceus } \\
\text { P.ostreatus } \\
\text { C.unicolar } \\
\text { G.lucidum } \\
\text { A.niger } \\
\text { P. verriculosum } \\
\text { T.liqnorum }\end{array}$ & $\begin{array}{l}16,7 \\
16,9 \\
15,8 \\
15,2 \\
17,4 \\
14,4 \\
14,2 \\
11,7 \\
12,5 \\
10,8\end{array}$ & $\begin{array}{l}11,2 \\
10,9 \\
10,1 \\
10,5 \\
12,1 \\
11,1 \\
10,9 \\
7,9 \\
8,9 \\
7,8\end{array}$ & $\begin{array}{l}2,9 \\
2,8 \\
2,4 \\
2,3 \\
3,0 \\
2,6 \\
2,7 \\
2,7 \\
2,6 \\
2,0\end{array}$ & $\begin{array}{l}24,1 \\
24,5 \\
25,2 \\
25,0 \\
22,0 \\
23,2 \\
22,8 \\
25,0 \\
27,1 \\
24,3\end{array}$ & $\begin{array}{l}5,8 \\
5,7 \\
5,0 \\
4,9 \\
5,2 \\
4,7 \\
4,9 \\
4,3 \\
4,7 \\
3,9\end{array}$ & $\begin{array}{l}0,90 \\
0,84 \\
0,80 \\
0,84 \\
0,78 \\
0,73 \\
0,64 \\
0,68 \\
0,72 \\
0,56\end{array}$ \\
\hline
\end{tabular}

полученных путем микробиологического обогащения белком отходов сельского хозяйства.

К преимуществам препаратов грибного происхождения следует также отнести и низкое содержание (максимум 1,7\%) в них нуклеиновых кислот, количество которых в препаратах бактериального происхождения доходит до 16\%[10].

Одним из отличительных особенностей, используемых в ходе работы грибов, является обогащение лигноцеллюлозных отходов не только белками, но и липидами, содержащими до $60 \%$ и более ненасыщенных жирных кислот. Анализ жирнокислотного состава липидов показало, что среди ненасыщенных кислот преобладает линолевая кислота. Кроме того, в спектре жирных кислот полученных препаратов установлено присутствие арахидоновой кислоты.

Как видно из таблицы 1, что в процессе микробиологической конверсии не происходит только обогащение белком и другим физиологически активными веществам, но и обнаруживается глубокое разложение и перестройка полисахаридного комплекса отходов (табл. 1). Поскольку, снижается общее количество углеводов и увеличивается содержание легкоутилизируе- мых сахаров(табл.2). Сравнительное изучение состава углеводов биомасс, полученных при ГК и ТФФ, показало, что субстраты обогащенные мицелиальными грибами в условиях ТФФ значительно богаче углеводами спирто- и водно-растворимых фракций. Отмечены существенные различия в углеводном составе полученных препаратов от используемого продуцента - гриба. Количество легкоутилизируемых (гемицеллюлозы) сахаров в ферментированных базидиальными грибами субстратах намного выше, чем в субстратах обогащенных микромицетами, а трудногидролизуемые (лигнина) наоборот.

Питательная ценность растительных отходов определяется не только количественным содержанием легкоусвояемых сахаров, но и их качественным составом. Анализы показали, что в этом аспекте полученные продукты можно считать полноценными, поскольку, их легкоусваиваемые фракции сахаров представлены арабинозой, ксилозой, фруктозой, маннозой, галактозой, глюкозой и в некоторых случаях целлобиозой.

Таким образом, полученные результаты показали, что растительные отходы, имеющие низкие кормовые свойства, за счет биоконверсии их мицелиальными грибами могут быть превращены в ценный кормовой продукт. 
Таблица 2. Фракционный состав (\%) белково-углеводных продуктов

\begin{tabular}{|c|c|c|c|c|}
\hline Грибы & $\begin{array}{l}\text { Спирто- и водорастворимые } \\
\text { фракция }\end{array}$ & Гемицеллюлозы & Целлюлоза & лигнин \\
\hline \multicolumn{5}{|l|}{ ГК } \\
\hline $\begin{array}{l}\text { T, hirsutus } \\
\text { T.versicolor } \\
\text { B.adusta } \\
\text { P.aqariceus } \\
\text { P.ostreatus } \\
\text { A.niger } \\
\text { P. verriculosum } \\
\text { T.liqnorum }\end{array}$ & $\begin{array}{l}2,4 / 1,6 \\
2,3 / 1,6 \\
2,7 / 1,6 \\
2,3 / 1,4 \\
2,7 / 1,5 \\
1,8 / 1,1 \\
0,8 / 1,3 \\
1,3 / 1,2\end{array}$ & $\begin{array}{l}18,5 \\
18,1 \\
21,0 \\
20,3 \\
18,9 \\
12,3 \\
10,3 \\
14,3\end{array}$ & $\begin{array}{l}19,5 \\
19,2 \\
20,9 \\
20,8 \\
17,8 \\
21,1 \\
20,3 \\
19,4\end{array}$ & $\begin{array}{l}16,7 \\
16,4 \\
20,1 \\
20,4 \\
17,2 \\
25,4 \\
27,7 \\
29,5\end{array}$ \\
\hline \multicolumn{5}{|l|}{ ТФФ } \\
\hline $\begin{array}{l}\text { T, hirsutus } \\
\text { T.versicolor } \\
\text { B.adusta } \\
\text { P.aqariceus } \\
\text { P.ostreatus } \\
\text { A.niger } \\
\text { P. verriculosum } \\
\text { T.liqnorum }\end{array}$ & $\begin{array}{l}3,7 / 6,6 \\
3,4 / 6,7 \\
4,4 / 5,5 \\
4,1 / 5,2 \\
3,8 / 6,5 \\
5,3 / 5,1 \\
2,8 / 3,3 \\
4,1 / 5,2\end{array}$ & $\begin{array}{l}16,7 \\
16,6 \\
17,9 \\
17,8 \\
16,0 \\
11,3 \\
8,7 \\
10,2\end{array}$ & $\begin{array}{l}17,4 \\
17,7 \\
19,1 \\
18,1 \\
16,4 \\
20,3 \\
19,0 \\
18,1\end{array}$ & $\begin{array}{l}15,5 \\
15,7 \\
17,1 \\
16,9 \\
16,1 \\
23,8 \\
25,7 \\
28,7\end{array}$ \\
\hline Контроль & $0,7-1,0 / 0,6-0,7$ & $26,7-31,3$ & $32,2-37,8$ & $31,4-35,3$ \\
\hline
\end{tabular}

\section{ЛИТЕРАТУРА}

1. Бабицкая В.Г. Грибы — продуценты физиологически активных веществ на лигноцеллюлозе: биология и культивирование. Автореферат диссертации на соискание доктора биологических наук. Москва, 1991, 32с.

2. Белова Н. В. Грибы белой гнили древесины и возможность их использования для утилизации отходов.// Биотехнология, 2005, № 4, с. 55-58.

3. Брагинцева Л. М. Грибы источник биологически активных веществ // Успехи медицинской микологии, 2001, т. 1, с. 242-245

4. Бухало А. С. Высшие съедобные базидиомицеты в чистой культуре. Киев: Наукова думка, 1988, 144 с.

5. Горшина, Е. С. Грибы рода Trametes Fr. как объекты биотехнологии./ Современная микология в России (второй съезд микологов России). М.: НА Микология, 2008, т. 2, с. 328-329.

6. Ермаков А.И. (под. ред.) Методы биохимических исследований растений, Л.: Колос, 1972, 456 с.

7. Кивилёв К. В. Перспективы биотехнологического использования дерево-разрушающих грибов // Прикл. биохимия и микробиология, 2005, т. 35, № 5, c. 659-667.

8. Кожемякина Н.В., Ананьева Е.П., Турина С. В. Условия культивирования, состав и биологическая активность мицелия Flammulina velutipes (Fr.) P. Krást. // Прикладная биохимия и микробиология, 2010, т. 45, № 5, с. 583-585.

9. Методы экспериментальной микологии (Под. ред. Билай В. И.) Киев: Наукова думка, 1982, 500с.

10. Мурадов П. 3. Основы биоконверсии ратительных субстратов.Баку: Из-во «Элм», 2003, 114с.

11. Мурадов П.З., Гасымов Ш. Н., Гахраманова Ф.Х. и др. Ксилотрофные грибы как активные деструкторы растительных отходов.//Вестник МГОУ, серия «Естественные науки», 2009, № 1, с. 109-112.

12. Практикум по биохимии (Под. ред. Н. П. Мешковой и С. Е. Северина.). М: МГУ, 1979, 430 с.

13. Хотянович А.В., Веденеева Н. В., Кубарева 3. И. //Прикладная биохимия и микробиология, 1972, т. 8, № 2, с. 186-190.

14. Шарков В.И., Куйбина Н. И., Соловьев Ю. П., Павлова Т. А. Количественный анализ растительного сырья. Москва: Лесная промышленность, 1976, 72 с.

15. Akinyele B.J., Olaniyi 0. 0. and Arotupin D. J. Bioconversion of Selected Agricultural Wastes and Associated Enzymes by Volvariella volvacea: An Edible Mushroom.// Research Journal of Microbiology, 2011, v.6, p.63-70.

16. Bharathiraja S., Suriya J., Krishnan M., Manivasagan P., Kim S.-K. Production of Enzymes From Agricultural Wastes and Their Potential Industrial Applications. Adv. Food Nutr. Res. 2017, v.80, p.125-148.

17. Cutrim F.M., Ramos E. C. Abreu M. C., Godinho A. S. et al. A Study of Chemical Composition and Enzymatic Hydrolysis of Solid Organic Waste from Agrosilvopastoral Systems.//J. Braz. Chem. Soc., 2019, v. 30, N. 9, p.1955-1963, 
18. Dashtban M., Schraft H., Qin W. Fungal bioconversion of lignocellulosic. Opportunities and Perspectives // Int.J.Biol.Sci., 2009, v. 5(6), p. $578-595$.

19. Dungani R., Karina M., Sulaeman A., Hermawan D. and Hadiyane A. Agricultural Waste Fibers Towards Sustainability and Advanced Utilization: A Review. //Asian Journal of Plant Sciences, 2016, v.15, p.42-55.

20. Isikgora F.H, Becer C. R. Lignocellulosic Biomass: A Sustainable Platform for Production of Bio-Based Chemicals and Polymers.//Polymer Chemistry, 2015, v.6, p. 4497-4559

21. Owusu, P.A., Asumadu-Sarkodie, S. A review of renewable energy sources, sustainability issues and climate change mitigation.// Cogent Engineering, 2016, 3(1), 1167990. https://doi.org/10.1080/23311916.2016.1167990

22. Poppa J., Laknerb Z., Harangi-Rákosa M., Fáric M. The effect of bioenergy expansion: Food, energy, and environment.//Renewable and Sustainable Energy Reviews, 2014, v.32, p.559-578

\section{○ Бахшалиев Арзу Елмар оглы ( baxshaliyev.arzu@mail.ru ), Мусаева Вусала Гаджи гызы ( efendiyev.nigar@mail.ru ), \\ Гусейнова Афсана Энвер гызы ( efsane_huseynova@mail.ru ),}

Нематова Улкар Вагиф гызы ( azmbi@mail.ru ), Гасанова Арзу Расул гызы ( arzu.h85@mail.ru ).

Журнал «Современная наука: актуальные проблемы теории и практики»

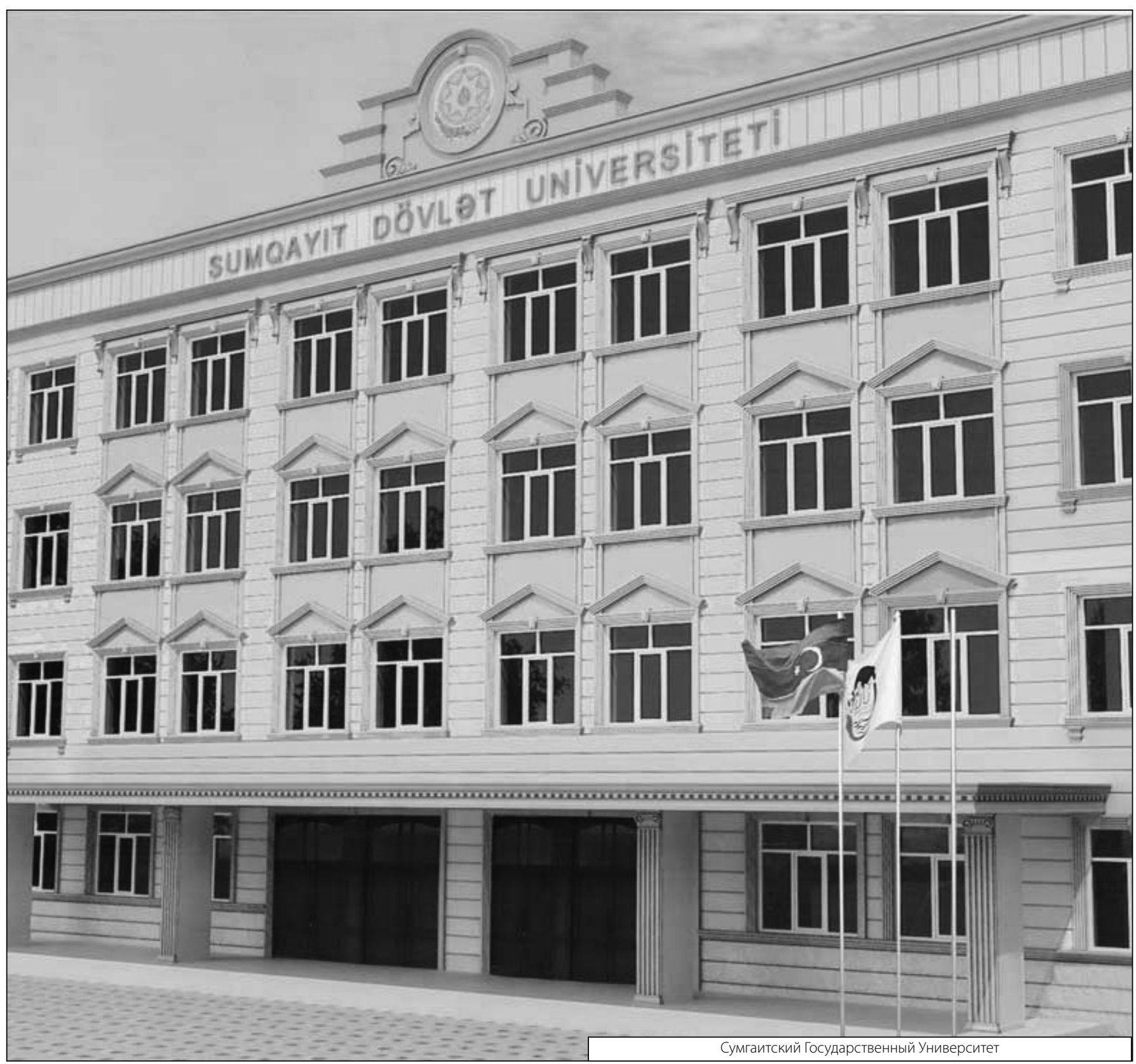

